\title{
The dark side of NY-LON: \\ Financial centres and the global financial crisis
}

\author{
Dariusz Wójcik \\ School of Geography and the Environment and St. Peter's College, Oxford University \\ South Parks Road, Oxford OX1 3QY, United Kingdom \\ dariusz.wojcik@spc.ox.ac.uk
}

\begin{abstract}
School of Geography and the Environment, Oxford University, Working Papers in Employment, Work and Finance 11-12
\end{abstract}

\begin{abstract}
This paper brings financial centres into the debate on the causes and consequences of the global financial crisis, by focusing on New York and London. It argues that the degree of commonality, complementarity and connectivity between the two leading global financial centres justifies the use of the term 'the New York - London axis' (the axis). It shows that the global financial crisis 2007-9 originated to large extent in the axis rather than in an abstract space of financial markets. The dominance of the axis in global finance can be easily underestimated, and evidence suggests that contrary to expectations the axis is not in decline. Implications are drawn for the future of Asian financial centres and the global financial reform. If global finance is to change, the New York - London axis has to change. Debate on the reform has to take the reality of global financial centres seriously.
\end{abstract}

Keywords: New York, London, Asia, financial centres, financial crisis, financial reform

\section{Acknowledgements}

I am grateful to Karen Lai, James Faulconbridge. Andrew Jones and Gordon L Clark for their comments.

\section{Financial centres in question}

Financial centres do not exist as an established object of enquiry in economics. Geographical economics, while focused on explaining the distribution of economic activity, has little to say about capital flows or financial services. This is patently obvious when one reads the World Development Report 2009 based on geographical economics, with very few references to finance (Hart, 2010). One of the closest encounters between geographical economics and finance was a symposium organized by the Federal Reserve Bank of Kansas City in 2006, entitled The New Economic Geography: Effects and Policy Implications, with a session on Consequences for Financial Markets and Global Saving and Investment. The only paper on finance within the session analyses only data by countries, and does not mention the word financial centre (Prasad, Rajan and Subramanian, 2006). Even Paul Krugman seems to wear two hats: when he talks about finance or the financial crisis, he does not mention geography; when he talks about geography he does not mention finance. 
Ignoring financial centres when putting finance and geographical economics together is most puzzling given that geographical economics pays so much attention to concentration of economic activity and development of cities. Financial economics, partly influenced by the success of geographical economics, has paid increasing attention to distance, but not to financial centres (Wójcik, 2009). One has to go back to Charles Kindleberger to find an influential economist who paid serious attention to financial centres and their role in the performance of financial markets (1974). He knew that to understand the real world of finance we have to consider the formation of financial centres. With very few exceptions in economics this message has been lost (Grote and Lo, 2002; Gehrig, 1998).

Surely one would think that the fame of geographical economics and the recent global financial crisis should make economists think seriously about financial centres. The best books written thus far on the financial crisis from an anthropological perspective by Karen Ho (2009) and Gillian Tett (2009) focus on the cultural milieu of the Wall Street. The most influential accounts by economists, however, do not utter the word financial centre (Shiller 2008, Stiglitz 2010, Rajan 2010). The Institute for New Economic Thinking created in New York in the wake of the crisis "to broaden and accelerate the development of new economic thinking that can lead to solutions for the great challenges of the 21 st century", covers economic history and political economy, shows interest in complexity thinking, chaos theory, but has no mention of economic geography. In contrast, media constantly refer to the Wall Street and the City of London as the sources of financial power and origins of the financial crisis, and speculate on the rise of Shanghai as a global financial centre to challenge New York and London, as well as on various possible combinations of leading financial centres such as NY-LON-KONG (Elliot 2008). It would seem that the topic of financial centres is good for media but not for a serious academic pursuit as economists understand it.

In this context, it is an opportunity for and responsibility of economic geographers to remind the world of the significance of financial centres as concentrations of financial activity, expertise, and power. Global finance or financial crises cannot be understood without considering financial centres. This paper brings financial centres into the debate on the causes and consequences of the global financial crisis, by focusing on New York and London. It argues that the degree of commonality, complementarity and connectivity between the two leading global financial centres justifies the use of the term 'the New York - London axis' (the axis). The dominance of the axis in global finance is often underestimated. The crisis did not originate in an abstract space of financial markets; to a large extent it originated in the axis. This has major implications for the future. First, the development of Asian financial centres involves challenging the axis (rather than New York and London individually), joining the axis or a combination thereof. Second, global financial reform needs to target the axis. To put it simply, if global finance is to change, the New York - London axis has to change. Discussion on the reform stresses the necessity of multilateral agreements with global scope, and in doing so runs the risk of obscuring the role of the axis. The difficulty of reaching a broad multilateral agreement offers an excuse for inaction and serves the interest of those who want to preserve the status quo of power in the axis.

\section{The New York - London axis: conceptual roots and extensions}

The study of relations between cities underwent a well-documented shift from focus on national urban systems to relations between cities at an international level. A major milestone was the world city hypothesis by John Friedmann (1986), which linked urbanization to global economic processes, with manufacturing activity migrating 
from high to low wage regions and countries creating demand for control functions, the realm of corporate headquarters and producer services, concentrated in select cities. In his hierarchy, Friedmann places London and New York as two of the six primary cities in core countries, alongside Paris, Chicago, Los Angeles, and Tokyo. Building on Friedmann's work, Saskia Sassen (1991) developed a global city hypothesis, with focus on producer services, rather than corporate headquarters of manufacturing and non-producer service firms, as the main actors of global cities, and on New York, London, and Tokyo. While both world and global city concepts place cities in the context of global economic change they stress international competition and hierarchy between cities, a focus also reflected in work on financial centres (Reed 1981).

The next major shift came with Manuel Castells' work on network society, stressing the prevalence of the space of flows (money, people, goods, and information) over space of places (cities and countries) in contemporary economy (1996). This led to rethinking the system of cities as a network, whereby the position and power of a city is determined by its connectivity with other cities, and relations between cities pictured as a complex combination of collaboration and competition. A remarkable effort in this area is the World City Network (WCN) project, with broad empirical focus, covering office networks of producer services firms in hundreds of cities (Beaverstock et al., 2000; Taylor, 2004). This shift from competition and hierarchy to networks and relations between cities has also been articulated in works on financial centres (Beaverstock et al., 2001; Faulconbridge, 2004).

Within research on inter-city relations attention to finance has increased. For Friedmann, finance is one of many sectors that assist corporate headquarters, but the latter are still considered decisive for the hierarchy of world cities. Sassen affords finance a more privileged place, discussing financial services before and in more detail than any other producer services. Within the WCN the position of financial firms grew with time as well. In 2000 finance accounts for 34 out of 100 leading producer services firms; in 2008 for 75 out of 175 (Taylor et al., 2011a). In short, research in urban studies has reflected growing financialisation of economy and cities.

The leadership of New York and London at the top of the global network seems to have strengthened with time. While for Friedmann New York and London were two of 6 primary cities in core economies, and for Sassen they shared their global city status with Tokyo, according to the WCN, their connectivity is incomparable with any other cities. This phenomenon is referred to as the 'New York - London dyad', 'transatlantic core, 'apex of globalization' or 'global twin-cities' (Taylor et al., 2011a; Taylor, 2004). Castells (2010) refers to New York and London as the mega nodes of the global network. However, while hundreds of studies allude to the position of New York and London, there are no studies that focus specifically on relations between New York and London as financial centres, as if these relations were taken for granted. The global financial crisis makes this silence even less tenable.

To shed light on the relationship between New York and London as financial centres we use the term New York - London axis. Susan Strange used the term when referring to the special relationship between USA and the UK in matters of financial deregulation and re-regulation (1998, p.6). The term axis is used commonly (though not with reference to New York and London) in international relations literature implying agreement or alliance between two or more countries. Another meaning of the word axis, according to the Oxford English Dictionary is 'a line through the centre of a rotating object'. This is close to Peter Hall's observation that 'London and New York are very special cities and in this sense represent the two poles of a transatlantic 
metropolis" (2003, p.31). Links between New York and London have been so central to the process of globalization in the last century that the level of globalization of other cities is strongly affected by their connectivity to the axis.

The term axis is less neutral than dyad, and brings up associations with power. The New York - London axis describes a special relationship between these two cities in financial matters, underpinned by a special relationship between the USA and the UK, central to the operation of global financial markets and the process of financial globalization. To be sure, the objective is not to put the New York-London axis on an unshakeable pedestal, as it is acknowledged that the power of the axis is embedded within its relations with other financial centres. The axis can be understood as an element of the WCN, but is more than a dyad leading in terms of density of flows. It has an explicit political element. The term axis is used to stress the uniqueness of the New York - London dyad among other relations in the world city network and to explore its implications.

\section{A brief history of the axis}

With USA as an offshoot of the British Empire, New York as a financial centre has its roots in London. New York won the domestic competition for financial supremacy throughout the first half of the $19^{\text {th }}$ century, due in good measure to its role in intermediating trade between Europe and the rest of the USA, and later in channeling British capital into the US economy (Kindleberger, 1974). US business was an important contributor to London's supremacy as the global financial centre in the $19^{\text {th }}$ century, just as London contributed to New York's rise as an international financial centre. Key players in the growth of New York have been British merchant banks such as Baring Brothers, and Brown, Shipley \& Co. Those that did not appreciate the centrality of the axis, such as the Rothschilds, were outcompeted by those that forged and benefited from it, such as JP Morgan (Morrison and Wilhelm, 2007).

Despite the expansion of the US economy, adverse impacts of WWI and a gradual decline of the British empire and economic prowess, New York never consistently succeeded London as a global financial centre. Even in the interwar period cooperation between the centres was intense, as the USA tried to help Great Britain restore the gold-sterling standard, by maintaining low interest rates and artificially high USD to GBP exchange rate. According to Michie (2006) this actually fuelled a lending boom in the USA, which followed by the Great Crash and the Great Depression slowed down the growth of New York as a financial centre. On the other side of the Atlantic, the dogged attempts at restoring the gold-sterling standard, while serving the City had negative implications for British manufacturing.

With financial regulation after 1933, Roosevelt's New Deal, and the establishment of the IMF and the World Bank after the Bretton Woods Conference in 1944, the power moved from Wall Street to Washington D.C. London did not flourish either, struggling with depression in British and European economy, and destruction of WWII. Public and domestic finance dominated over private and international finance on both sides of the Atlantic from 1930s to late 1950s, marking the lowest point of the axis in their $20^{\text {th }}$ century history. New York was a larger financial centre, but its power was based almost entirely on domestic market. Importantly, though the international power of Wall Street was contained, the domestic power of New York was consolidated, as securities market regulation contributed to the demise of regional exchanges, as well as nation-wide expansion of New York headquartered brokerage firms like Merrill Lynch (Michie, 2006). 
In late 1950s Euromarkets breathed life back into the axis. Key initial decision was the agreement of the Bank of England in 1958 to allow British banks to take deposits and make loans in USD (Strange 1997). In late 60s, $80 \%$ of Euromarket borrowing and lending was conducted through London (Cassis, 2006). Euromarkets were dominated by US bank branches in London, pushed out of the US to escape restrictive banking regulations, which aimed at preventing capital outflow from the USA. As Cassis put it "while American banking legislation thus strengthened London's international role to the detriment of New York's, American banks took full advantage of the situation, dominating the Euromarkets and integrating them into their global strategy" (p.227).

The shift to floating currencies in 1970s contributed to a boom in foreign currency trading, which concentrated in New York and London. This way the power was released from Washington D.C., but not so much to New York itself but to the New York-London axis, now integrated more then ever before. In Andrew Walter's words "London regained its position as the centre for international financial business, but this business was centred on the dollar and the major players were American banks and their clients" (1991, 182). As Susan Strange put it "who can say that the internationalization of American banking would have taken place so fast and furiously if London had not been there, ready and waiting with 'Welcome' on the mat?" (1997, p.38). In 1970s London established its position as the centre of US banks servicing US corporations operating in Europe, and became the centre for recycling petrodollars, an activity conducted mainly by US banks.

After chaotic 1970s, consistent financial deregulation in the USA and the UK of 1980s allowed the axis to boom. The Big Bang of 1986 unleashed a new wave of US banks entering and consolidating their role in London. It also speeded up the transition from the culture of class privilege to smartness and more open hiring practices, making London more like New York (Leyshon and Thrift, 1995). Canary Wharf, a new prime location for finance developed in early 1990s, occupied mostly by large institutions, operated more like New York than the traditional City, with a myriad of small financial firms (Amin and Thrift, 1992). In the same period, Tokyo challenged the axis, but it relied mainly on domestic market, with relatively few links with foreign institutions. Investment bankers in Tokyo never lost a sense of inferiority in relation to Wall Street and the City (Miyazaki, 2003). In 1991 Tokyo imploded under the weight of a real estate bubble, and has not recovered since.

The accelerated financial integration in the European Union of 1990s and 2000s has consolidated the role of London as a centre of European wholesale finance and a gateway for US financial institutions. There were fears of Frankfurt challenging London, but these underestimated the power of London and ignored the role of the axis. London became the centre of financial transactions in Euro. A wave of mergers and acquisitions following the launch of the Euro offered lucrative deals for Londonbased investment banks. London has also become the agent of Wall Street's shareholder value revolution of 1980s and 1990s, which spread to Europe in late 1990s and early 2000s (Wójcik, 2002). Security concerns after 9/11 and more stringent reporting requirements in the USA of the Sarbanes-Oxley Act further reinforced the position of London in the axis. New York, however, boomed as a financial centre, as further deregulation, with the repeal of the Glass Steagall Act in 1999 and Commodity Futures Modernization Act of 2000, paved the way for unprecedented profits and bonuses for Wall Street investment banks.

Throughout history, the development of the New York-London axis has been underpinned by strong commonalities and complementarities. The cities share a 
common language and common law, and a strong tradition of economic and political liberalism, a fertile ground for belief in self-regulation of business and finance, as well corporate governance and accounting standards geared towards business owners rather than other stakeholders (Morck, 2005). New York and London form the financial axis of the Anglo-American (Anglo-Saxon) culture. Its political, cultural and business elites interact closely, leading to a whole lifestyle based on a fusion of London and New York (Smith, 2005). This led to the term NY-LON, coined in the Newsweek's article stating, "as different as New York and London are, a growing number of people are living, working and playing in the two cities as if they were one" (McGuire and Chan, 2000, p.42).

While commonalities between New York and London allow financial firms and professionals move almost seamlessly between the two centres, lowering the cost of interactions, complementarities create opportunities, making interactions highly profitable. While New York commands access to the largest and most liquid domestic financial market in the world, London's physical, political and historical geography implies access to a different time zone, European markets, and global connections (e.g. with India, Hong Kong and Australia) - legacy of commonwealth. London is the place where US banks can employ French and German speaking experts, who want to stay close to their home countries. Taking advantage of its sheer liquid domestic market, and the deepest pool of financial engineering talent, New York leads financial innovation (Strange, 1997). Hedge funds come from the USA, and so do venture capital and private equity. Most new products and methods of trading in the global securities markets emanated from New York (Michie, 2006). London, in turn, has specialized as a centre, where financial firms (with US banks in the lead) adapt financial innovation from the USA to foreign and international markets. A number of innovations in US retail banking, including data processing centres and telephone banking, have been adopted in the UK before spreading to the rest of Europe (Leyshon and Pollard, 2000).

Connectivity between London and New York is also served by physical infrastructure. No cities are connected by a denser web of fiber optics lines, more regular flights or transmit more information between each other (Warf, 2006). The world's first teleport located on Staten Island in 1981, an office park with satellite earth stations connected to fiber optic cables, was operated jointly by Merrill Lynch and the Port Authority of New York and New Jersey (Warf, 1995), highlighting the role of finance in forging connections between the two cities. It is a combination of commonalities and complementarities that has driven the connectivity of New York and London as financial centres in the global urban and economic system.

\section{The axis in the global financial crisis}

Interpreting the global financial crisis we need to acknowledge the role of the New York - London axis. If we start with the house price bubble fuelled by mortgage lending, we should note that in the UK, property prices in London in late 1990s started an ascent earlier and by 2007 grew by a higher percentage than anywhere else in the UK. In the USA, New York was among leading cities in terms of property price increases in early 2000s (Martin, 2010). As global media centres, New York and London house media companies that sustained the irrational exuberance, perpetuating the myth of property as a safe and profitable investment, a behavior undoubtedly influenced by buoyant real estate markets in these cities (Shiller, 2008).

Another explanation of the crisis stresses the role of global trade and financial imbalances. Large net exporters (mainly China) have been recycling their currency reserves investing in large net importing countries (mainly the USA but also the UK), 
thus contributing to low interest rates and a glut of liquidity available for lending in the latter group of countries (Rajan, 2010). While this explanation is rooted in macroeconomics, the axis is relevant to it. New York and London are the financial centres of countries with the largest and one of the largest current account deficits respectively. Looking for foreign (particularly portfolio) investments, national governments, sovereign wealth funds, and private investors from surplus economies turn to New York and London as places of investment or through which investments can be identified. The axis facilitates the recycling of global imbalances.

Financial deregulation at the root of the crisis was led by the USA and the UK. The repeal of Glass Steagall Act allowed deposit taking banks develop investment banking business; the Commodity Futures Modernization Act of 2000 left derivatives and OTC markets unregulated; while the Financial Services Authority in the UK maintained a flexible regulation regime, relying on self-regulation (Johnson and Kwak, 2010). Active lobbying of the financial industry contributed to deregulation, with competitive threat from foreign financial centres as one of the lobbyists' major arguments. Financial companies, with investment banks in the lead, mostly operating in both New York and London could play US and UK authorities against each other to prevent and counteract restrictive regulatory measures. The move towards 'light touch' regulation was "a product not only of narrow sectoral and political interest but also of spatial competition" (French, Leyshon and Thrift, 2009, p.292).

Financial deregulation allowed the emergence of a shadow banking system in the USA, with investment banks (such as Bear Stearns, Goldman Sachs, Lehman Brothers, Merrill Lynch, and Morgan Stanley), and investment banking arms of bank holding companies (such as JPMorgan Chase and Citigroup) as key players. They were major buyers of mortgages and asset-backed securities from mortgage originators and other banks; inventors of collaterlised debt obligations (CDOs) and credit default swaps (CDS) (Tett, 2009); major sellers of CDOs to institutional investors around the world; and major investors in these assets. All of the key investment banks involved were the icons of Wall Street, headquartered in New York, with major offices and operations in London. Securitization of mortgages was for the first time exported from the USA in 1986 through Salomon Brothers' office in London, which sold securitized mortgages to investors in the UK and Europe (Wainwright, 2009). In 2000s London was by far the leading centre of mortgage securitization in Europe, for both UK and foreign mortgages (Aalbers, 2009).

The operation of the shadow financial system through the axis can be illustrated with New York-headquartered AIG, one of the world's largest insurance companies. In September 2008 AIG was bailed out by the US to prevent its imminent bankruptcy, caused almost single-handedly by AIG Financial Products (AIG FP), a subsidiary headquartered in Fairfield, CT (an extension of the New York city-region along the Northern Coast of Long Island Bay), with main operations in London. AIG FP in London was a leader in the issuance of CDS, and the sale of CDS as well as CDOs to customers in the USA (such as Goldman Sachs) and Europe (such as Société Générale). The lowest amount that the AIG FP CEO in London, Joseph J. Cassano awarded himself annually between 2002 and 2007 was \$38m. Prior to 2007, AIG FP was not only the most profitable part of AIG, but was also referred to as the "golden goose for the entire (Wall) Street" (National Commission, 2011), reflecting its key role as the conduit of CDO and CDS production and distribution in Europe.

A lesser-known factor that facilitated the operation of the shadow banking system involves offshore financial centres, connected to and co-established by financial firms from New York and London (Palan, Murphy and Chavagneux, 2010). Granite Master 
Issuer Plc \& Associates, a vehicle used by Northern Rock for its reckless investments in CDOs and related instruments, was registered in Jersey, which helped to obscure its activities from the FSA. Many Special Purpose and Special Investment Vehicles used by US banks to create and finance CDOs were registered in tax havens (Tett, 2009). Another question mark is the role the International Financial Services Centre Dublin in the crisis, which was created mainly by the City and Wall Street firms when the axis boomed in 1990s, taking advantage of Ireland's commonalities with the UK and the US market environments (Warf, 1995). Indeed one could ask the question whether the disastrous attempt of Iceland to become 'the investment bank' of Scandinavia was not helped by its convenient location on an alternative flight route between London and New York. The availability of attractive golf courses in both Ireland and Iceland could have also played a part, as they serve as an extension of office space for investment bankers (Ho, 2009).

Accomplices of investment banks in the shadow banking system were rating agencies, which through their high ratings of CDOs (paid by investment banks) made them attractive to institutional investors, such as pension and mutual funds. The largest agencies - Standard \& Poors and Moody's are headquartered in New York; the third largest - Fitch Ratings has global headquarters split between New York and London. We can and should extend the list of suspects to accountancy companies, which were supposed to evaluate financial affairs of banks and warn the public; law firms, which were signing off investment banks' contracts as not only legal but also undertaken in good faith; as well as management consultants involved in advisory work for corporations and institutional investors. New York and London are the leading centres of global accountancy, legal services, and management consultancy networks. We should consider the global financial crisis as a failure of not only the financial sector, but of the whole producer services complex.

The New York - London axis was an important component of the multi-causal mix that underpinned the global financial crisis. New York and London have served as platforms for firms and individuals, as social and cultural milieus in which the types of behavior - an explosive combination of hubris and complacency - fuelling the crisis flourished. To be sure, the benefits of the financial sector bubble in New York and London were not shared with all people living and working in these cities. Nevertheless, a large number of firms and individuals from these cities and operating through them started the bubbles, and then spread them to the rest of their countries and the world. This way they established themselves at the top of a pyramid scheme and benefited most. Those, often in peripheral locations, far from the axis, joined the pyramid last and lost most. We should remember that the Ponzi features intrinsic to asset bubbles have a geographical dimension at both country and urban level (Kindleberger and Aliber, 2005; Harvey, 2011). Evidence suggests that in the wake of the crisis the income gaps between New York and the rest of the USA, and London and the rest of the UK, have grown (Gaponomics, 2011).

\section{Underestimated power and exaggerated decline: stocks, flows and networks}

Let us consider the most recent data on the WCN (Taylor et al., 2011). According to the Financial Command Index, describing the geography of headquarters of the leading financial service firms, New York comes at the top, followed by London with $60.71 \%$ of New York's weight (with Zürich in the third place with 37.5\%). According to Financial Network Connectivity, using data on office networks of the 75 financial service firms, London claims the top spot, followed by New York with $96 \%$ of London's connectivity (and Hong Kong third with 93\%). New York and London share the top two places in terms of connectivity in all other producer services 
(London in law and accountancy, New York in advertising and management consultancy). London and New York also claim the two top spots in the Global Financial Centres Index, launched by the City of London Corporation. London has maintained a narrow lead over New York since the first GFCI ranking in March 2007. Hong Kong has claimed the third place in all editions, except March 2009, when it was temporarily overtaken by Singapore. Xinhua-Dow Jones International Financial Centres Development Index launched in July 2010 as a joint venture of the official press agency of the PRC and the New York based financial information company, places New York ahead of London, with Tokyo in the third and Hong Kong in the fourth place. It is not surprising that organisations from both London and New York are directly involved in these rating exercises.

A disadvantage of the $\mathrm{WCN}$ and rating methodologies, however, is that they collapse differences in the position of individual centres into relatively small numerical differences. From the WCN it may seem that Hong Kong needs to improve only a tiny bit it to challenge New York and London. Even Madrid in the $10^{\text {th }}$ place, with $70 \%$ of financial network connectivity of London does not appear far behind. In GFCI, London has a rating of 775, while Luxembourg ranked $21^{\text {st }}$ has a rating of 630 , only 7 points behind Paris. Xinhua-Dow Jones, gives New York a score of 88.4, while Copenhagen ranking $20^{\text {th }}$ has a score of 41.0 . Rating methodologies intentionally focus on the competitiveness of financial centres rather than their size, and use measures of market sentiment, based on surveys among practitioners, as an important input into ratings. This allows a significant degree of change in ratings and rankings over time. An enthusiast may praise this sensitivity to change in the landscape of financial centres, while a sceptic may see it as an attempt to feed media's hunger for news. An opponent may say that it is an expression of financial sector interests, as it suggests that the position of financial centres is fragile and may need to be protected, e.g. by permissive regulation. Our argument is that these ratings underestimate the dominance of New York and London in global finance and consequently underplay the role of the axis.

To quantify the role of New York and London in global finance, we complement synthetic ratings and connectivity measures with easier to interpret figures on financial flows and stocks managed and controlled by these cities: foreign exchange turnover, interest rate derivatives turnover, stock of external bank assets, stock trading value, as well as data on employment. The first four items cover key financial markets, while employment represents the ultimate stock of financial centres, crucial to the operation of localization and agglomeration economies, and through salaries and tax revenues, for the impact of financial centre on the urban economy. To be sure, all data except for employment are available for countries only. Nevertheless, existing studies suggest that the level of concentration of financial activities chosen above in New York (for the USA), and particularly in London (for the UK) is very high (Parr and Budd, 2000).

As figure 1 shows the Anglo-American share in global finance in 2010 was 32\% for cross-border bank assets, 53\% for stock trading, 55\% for forex, and $71 \%$ for interest rate derivatives. The figure also shows the share of the largest market other than the USA and the UK. Only in case of stock trading, UK and USA do not claim the two top spots. If one considered trading in foreign (cross-listed) stocks only, the share of the UK and the USA would however exceed $80 \%$ (Wójcik, 2011b). The position of the axis indicated by the figure is formidable. The figures shown are national, but given that international financial activities are likely to be more dispersed in Germany and China than in the USA, and are at least as concentrated in the UK as in Japan and 
France, the figure is a useful proxy of the relative position of the axis vis-à-vis foreign financial centres.

The Anglo-American share fluctuates over time, but the prevailing trend since 1995 is an increase. The only exception is stock trading, explained by the expansion of domestic stock markets in emerging economies. For forex, interest rate derivatives and external bank assets, the joint UK and US share in 2010 was higher than before the crisis. Thus, the often-expected decline of the Anglo-American financial power is at the very least exaggerated. The figure also illustrates important generic features of the axis. Its relative strength lies in securities (including stocks and derivatives) and trading (including securities and currencies) rather than traditional bank assets such as loans.

The focus of the axis on securities is confirmed by table 1, presenting data on financial sector employment in the leading centres of countries covered in figure 1. Tokyo, Paris, and leading Chinese centres may have comparable numbers of people employed in credit and insurance, but employment in the securities industry in these cities lags far behind New York and London. Even Boston and Chicago employ more people in the securities industry than Paris, while the industry is miniscule in Beijing, Shanghai and Frankfurt. Securities industry involves the production, distribution and exchange of securities. It consists primarily of investment banking and asset management, and constitutes the elite of the financial sector, with remuneration far exceeding that in credit and insurance or any other producer services (Wójcik, 2011a). Between 1998 and 2008, financial firms shed jobs in in credit and insurance in New York and London, but compensated for that with new (much more highly paid) jobs created in the securities industry.

\section{Asia: challenging or extending the axis?}

The rise of Asian financial centres can be considered in relation to the dynamics of the New York - London axis as a choice between or a combination of two options: joining the axis or challenging the axis. The very idea of networks implies that everyone can benefit from enlarging the network through positive network externalities. Congestion applies to agglomerations in space, but not to networks. As Sassen stated "there would be little if any gain for the financial markets and individual firms from crushing Tokyo or Hong Kong" (2001, p.174). The WCN research shows that after NY-LON the most important connections are those of London with Hong Kong, and New York with Hong Kong (Taylor et al., 2011). The tri-city of NY-LON-KONG would connect the leading English-speaking business centres in each 8-hour time zone. An alternative is a growing connectivity between NY-LON and the triad of Beijing, Shanghai and Hong Kong, the latter connected through strong complementarities, focusing on political, commercial, and offshore financial functions respectively (Lai, 2011). This would offer interesting complementarities globally, as New York at present offers more connections to Beijing, while London is more connected to Shanghai and Hong Kong (Taylor, 2011).

There are however limits to the NY-LON-KONG scenario or relationships between NY-LON and the Chinese triad. Although potential complementarities are enormous, the commonalities between NY-LON and Hong Kong (not to mention Shanghai and Beijing) are small compared to those between New York and London. The Chinese authorities may not wish any of its leading urban centres to be an extension of the New York-London axis. The UK and the USA have benefited in terms of international influence from underwriting the leading financial centres of the world, and probably in terms of growth, but definitely not in terms of economic stability and equity, which seem to be relatively high on the agenda in Beijing. By maintaining 
capital controls and restricting the activity of foreign banks in Mainland China, the PRC thus far contains its exposure to global financial markets and limits the influence of financial practices spreading from New York and London. Related is the issue of power within the potentially extended axis. China is unlikely to welcome Hong Kong as the third best in the axis dominated by NY-LON firms. In this context, it is worthwhile noting that Vincent Cheng, Chairman of the HSBC turned Time's slogan around suggesting HONG-NY-LON as a more appropriate forecast.

With financial reregulation looming on the horizon, the degree of connectivity in the WCN may stagnate or even diminish. Competition within the network may gain in relation to cooperation. As Taylor $(2011$, p.2) warns "in the good times cooperation will be seen as beneficial as the economy produces a win-win scenario but with the downturn prospects of losing will generate a more competitive relation between cities". The network may not be becoming more horizontal, as it was between 2000 and 2008. While it is risky to make any forecasts it is possible to identify areas of finance, where the tensions between extending and challenging the New York London axis are likely to play out. These will include: access of leading western investment banks to the Chinese stock market, and their relations with sovereign wealth funds; cross-listing of Chinese companies in London and New York, intermediated mainly by US investment banks, and often routed via OFCs like British Virgin Islands, triggering negative reactions from Beijing; and the response of Asian exchanges to the growing power of New York and London exchanges in the global stock market (Wójcik, 2011a; 2011b).

\section{The axis and the global financial reform}

Much of the discussion on the global financial reform assumes that the reform is a matter of decisions of state governments and inter-governmental organisations. The former Chief Economist of the IMF, however, expresses little faith in the role of the IMF or G20 (Rajan, 2010). The pressure to change global finance in his view must come from civil society, mobilized through social networks. In my view, for global finance to change, a significant degree of change must be generated internally within the financial sector, and given the concentration of key personnel, expertise, knowledge, transactions, and power of global finance in New York and London, the axis should also be considered in the ongoing debates. The Wall Street and the City represent communities that jointly bear significant responsibility for what had happened and what will happen in global finance. As Financial Times put it "What is now urgently needed is some moral authority from the government and also the financial sector" (Fried, 2011).

The issue of agency in relation to financial centres is complicated. According to the WCN approach the main agents are international producer services firms, cities themselves have little agency. Little, however, can be significant. Consider, for example the power of the City of London Corporation or securities industry lobby groups, such as the London Investment Banking Association, SIFMA in the USA, and International Securities Dealers Association with main offices in New York and London. In the name of reform and change, the participation and input of these organisations in the reform process should be fully transparent. The development of new organisations of finance professionals aimed explicitly at more sustainable and responsible finance should be promoted. This does not imply only a voluntary catharsis and reregulation, but also the possibility of positive financial innovation for the future.

Global finance depends a great deal on people and infrastructure in New York and London, and the argument that bankers working in these centres can pack their coffers 
and move elsewhere en masse is self-serving and exaggerated. As insiders themselves admit "only the most swingeing regulation would outweigh the City's agglomeration and time-zone benefits" (Guthrie, 2011, p.20). It is instructive to see that the main arguments used to stress the mobility of finance in early 2011 in London are thinly veiled threats from HSBC to move headquarters to Hong Kong, and from Barclays (now with an American CEO) to move to New York. For an international financial firm to give up its presence in the axis (particularly if extended by Hong Kong) is a difficult proposition. Consequently, banning undesirable and promoting desirable financial practices in the USA and the UK can achieve more than the opponents of financial reform want us to believe. The authorities of the states and cities hosting financial centres, with the US and the UK governments in the lead, can use the difficulty of obtaining an international, if not global, agreement for regulatory change in finance as an excuse for inadequate action. Global finance starts on Wall Street and in the City of London, and global financial reform has to recognize this.

Existing reform plans show little consideration for the role of financial centres, and no recognition of the New York - London connection. The Financial Crisis Inquiry Report in the USA talks about Wall Street on almost every single page, but mentions London only in the context of AIG FP. The reports of the House of Commons Commission on the Banking Crisis use the City in their titles, but hardly mention Wall Street or the USA. The Financial Stability Board hosted by BIS, the Global Financial Stability Report of the IMF (2010), and communications of the European Commission on financial services or supervision policy do not mention the word financial centre, London, New York, the City or the Wall Street. A major exception to the policy-makers' silence on financial centres is the Interim Report of the Independent Commission on Banking, which contains a whole section on the potential impact of proposed reform measures on the international competitiveness of the City, paying attention to its historical development, clustering, and relations between finance and professional business services (2011). On the other hand, the Report seems to advertise the observation that the position of the City is driven by foreign firms, which would be largely unaffected by the proposed reforms, as an assurance and a factor mitigating the costs of reform. As a result, the Report ignores London's international dimension as a facilitator of the crisis, and negative implications of international competition between financial centres for global financial stability.

\section{References}

Aalbers, M. 2009. The globalization and Europeanization of mortgage markets. International Journal of Urban and Regional Research 33/2: 389-410.

Amin, A., Thrift, N. (1992) Neo-Marshallian nodes in global networks. International Journal of Urban and Regional Research, 22: 571-87.

Beaverstock, J.V., Hoyler, M., Pain. K., Taylor, P.J. 2001. Comparing London and Frankfurt as World Cities: A Relational Study of Contemporary Urban Change. London: Anglo-German Foundation for the Study of Industrial Society.

Beaverstock, J.V., Smith, R.G. and Taylor, P.J. 2000. World city network: a new metageography. Annals of the Association of American Geographers 90/1: 123-134.

Cassis, Y. 2006. Capitals of Capital: A History of International Financial Centres, 1780-2005. Cambridge: Cambridge University Press. 
Castells, M. 2010. Globalisation, networking, urbanization: Reflections on the spatial dynamics of the information age. Urban Studies 47/13: 2737-2745.

Elliot, M. 2008. A tale of three cities. Time. 17 January.

Faulconbridge, J.R. 2004. London and Frankfurt in Europe's evolving financial centre network. Area 36/3: 235-244.

French, S., Leyshon, A., Thrift, N. 2009. A very geographical crisis: the making and breaking of the 2007-2008 financial crisis. Cambridge Journal of Regions, Economy and Society 2: 287-302.

Fried, B. 2011. Mandela's lessons in truth for City high-fliers. Financial Times, 7 April.

Friedmann, J. 1986. The world city hypothesis. Development and Change 17: 69-83.

Gaponomics: Regional income inequality has risen in many countries. What should be done about it? The Economist, 10 March, 2011.

Gehrig, T. 1998. Cities and the geography of financial centres. Discussion Paper 1894. London: Centre for Economic and Policy Research.

Grote, M.H. and Lo, V. (2002) A value chain approach to financial entres - the case of Frankfurt, Tijdschrift voor Economische en Sociale Geografie, 4, pp. 412-423.

Guthrie, J. 2011. Stability talks would stem bank diaspora backchat. Financial Times, 31 March, page 20 .

Hall, P. 2003. Londra, metropolis riluttante. Urbanistica, May-August: 21-31.

Hart, G. 2010. Redrawing the map of the world? Reflections on the World Development Report 2009. Economic Geography 86/4: 341-350.

Harvey, D. 2011. Roepke lecture in economic geography - Crisis, geographic disruptions and the uneven development of political responses. Economic Geography 87/1: 1-22.

Ho, K. 2009. Liquidated: An Ethnography of Wall Street. Durham and London: Duke University Press.

IMF 2010. Global Financial Stability Report: Sovereigns, Funding, and Systemic Liquidity. October. Washington DC: IMF.

Independent Commission on Banking 2011. Interim Report: Consultation on Reform Options. April. London: ICB.

Johnson, S. and Kwak, J. (2010) 13 Bankers: The Wall Street Takeover and the Next Financial Meltdown. New York: Pantheon.

Kindleberger, C.P., Aliber, R.Z. 2005. Manias, Panics and Crashes: A History of Financial Crises. Basingstoke and New York: Palgrave.

Kindleberger, C.P. (1974) The formation of financial centres: a study in comparative economic history. Princeton Studies in International Finance 36, Princeton University.

Lai, K. (2011) Differentiated markets: Shanghai, Beijing and Hong Kong in China's Financial Centre Network, Urban Studies (forthcoming). 
Leyshon, A., Pollard, J. 2000. Geographies of industrial convergence: the case of retail banking. Transactions of the Institute of British Geographers 25/2: 203-220.

Leyshon, A., Thrift, N. 1995. Geographies of financial exclusion: financial abandonment in Britain and the United States. Transactions of the Institute of British Geographers 20: 312-341.

Martin, R. 2010. The local geographies of the financial crisis: from the housing bubble to economic recession and beyond. Journal of Economic Geography. Advance Access.

McGuire, S. and Chan, M. 2000. The NY-LON life. Newsweek, 13 November, 40-47.

Michie, R.C. 2006. The Global Securities Market: A History. Oxford: Oxford University Press.

Miyazaki, H. 2003. The temporalities of the market. American Anthropologist 105/2: 25-65.

Morck, R. 2005. A History of Corporate Governance Around the World. National Bureau of Economic Research Conference Report.

Morrison, A. and Wilhelm, W. 2007. Investment Banking: Institutions, Politics, and Law. Oxford: Oxford University Press.

National Commission on the Causes of the Financial and Economic Crisis in the United States 2011. The Financial Crisis Inquiry Report.

Palan ,R., Murphy, R., Chavagneux, C. 2010. Tax Havens: How Globalization Really Works. Ithaca, NY: Cornell University Press.

Parr, J.B., Budd, L. 2000. Financial services and the urban system: an exploration. Urban Studies 37 (3): 593-610.

Prasad, E., Rajan, R.G., Subramanian, A. 2006. Patterns of International Capital Flows and Their Implications for Economic Development. Paper presented at the symposium on The New Economic Geography: Effects and Policy Implications at the Federal Reserve Bank of Kansas City, http://www.kansascityfed.org/publicat/sympos/2006/pdf/11Rajan.pdf

Rajan, R. 2010. Fault Lines: How Hidden Fractures Still Threaten the World Economy. Princeton: Princeton University Press.

Reed, H.C. 1981. The Pre-eminence of International Financial Centres. New York, NY: Praeger.

Sassen, S. 1991. The Global City: New York, London, Tokyo. Princeton, NJ: Princeton University Press.

Shiller, R. 2008. The Subprime Solution: How Today's Global Financial Crisis Happened, and What to Do about It. Princeton: Princeton University Press.

Smith, R.G. 2005. Networking the City. Geography 90/2: 172-176.

Stiglitz, J. 2010. Freefall: Free Markets and the Sinking of the Global Economy. London: Allen Lane.

Strange, S. 1998. Mad Money. Manchester: Manchester University Press. 
Strange, S. 1997. Casino Capitalism. Manchester: Manchester University Press.

Taylor, P.J. 2004. World City Network: A Global Urban Analysis. London: Routledge.

Taylor, P.J. 2011. Competition and cooperation between cities in globalization. GaWC Research Bulletin 351.

Taylor, P.J., Ni, P., Derudder, B., Hoyler, M., Huang, J., Witlox, F. 2011a. Global Urban Analysis: A Survey of Cities in Globalization. London: Earthscan.

Taylor, P.J., Hoyler, M., Pain, K., Vinciguerra, S. 2011b. Extensive and intensive globalizations: explicating the low connectivity puzzle of US cities using a city-dyad analysis. GaWC Research Bulletin 369.

Tett, G. 2009. Fool's Gold: How Unrestrained Greed Corrupted a Dream, Shattered Global Markets and Unleashed a Catastrophe. London: Abacus.

Von Peter, G. 2007. International banking centres: a network perspective. BIS Quarterly Review, December: 33-45.

Wainwright, T. 2009. Laying the foundations for a crisis: mapping the historicogeographical construction of residential mortgage backed securitization in the UK. International Journal of Urban and Regional Research 33/2: 372-388.

Walter, A. 1991. World Power and World Money: The Role of Hegemony and International Monetary Order. New York: St Martin's Press.

Warf, B. 2006. International Competition between satellite and fiber optic carriers: a geographic perspective. The Professional Geographer 58/1: 1-11.

Warf, B. 2000. New York: the Big Apple in the 1990s. Geoforum 31/4: 487-99.

Warf, B. 1995. Telecommunications and the changing geographies of knowledge transmission in the late $20^{\text {th }}$ century. Urban Studies 32/2: 361-78.

Wójcik, D. 2011a. The end of investment bank capitalism? An economic geography of financial jobs and power. Working Papers in Employment, Work and Finance 1107. School of Geography and the Environment, Oxford University. http://papers.ssrn.com/sol3/papers.cfm?abstract_id=1795162

Wójcik, D. 2011b. The Global Stock Market: Issuers, Investors, and Intermediaries in an Uneven World. Oxford: Oxford University Press.

Wójcik, D. 2009. The role of proximity in secondary equity markets, in G.L. Clark, A.D. Dixon and Ashby H.B. Monk (Eds) Managing Financial Risks: From Global to Local, pp. 140-162. Oxford: Oxford University Press.

Wójcik, D. 2002. Cross-border corporate ownership and capital market integration in Europe: evidence from portfolio and industrial holdings. Journal of Economic Geography, 2/4: 455-491. 


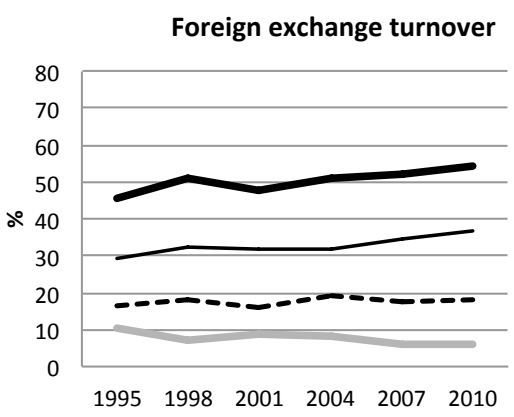

External bank assets

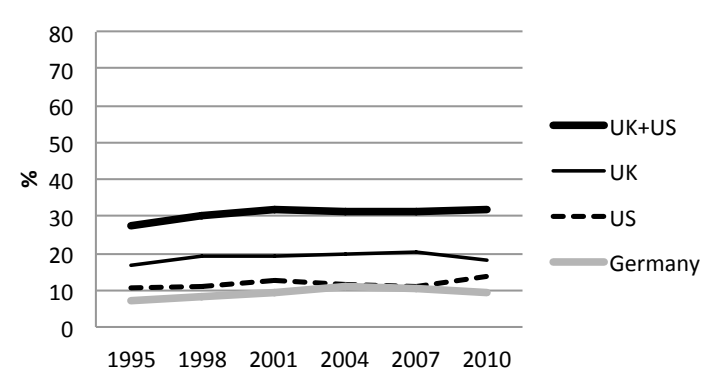

Interest rate derivatives turnover

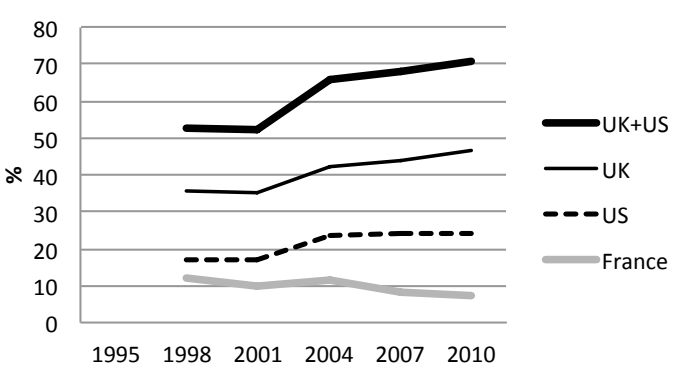

Stock trading value

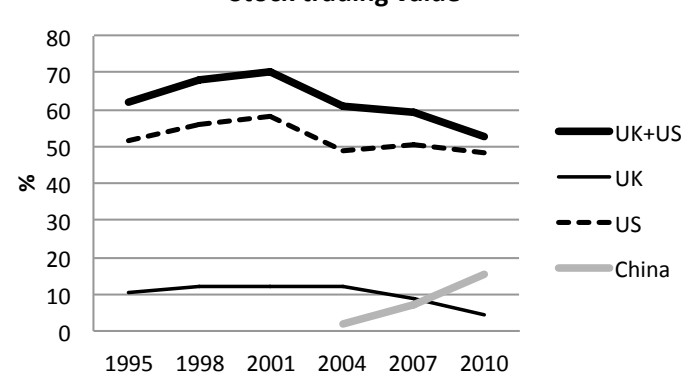

Figure 1. Shares of leading countries in selected global financial activities

Sources: Author based on data from the Bank for International Settlements, and the World Federation of Exchange.

\begin{tabular}{lllll}
\hline \multirow{2}{*}{ City } & \multicolumn{2}{l}{ Securities industry } & \multicolumn{2}{l}{ Credit \& insurance } \\
& 2008 & 1998 & 2008 & 1998 \\
\hline New York & 262 & 217 & 375 & 414 \\
London & 123 & 80 & 209 & 234 \\
Hong Kong & 70 & 55 & 137 & 114 \\
Boston & 68 & 58 & 125 & 121 \\
Tokyo & 62 & 77 & 296 & 392 \\
Chicago & 62 & 43 & 212 & 224 \\
Paris & 34 & 26 & 263 & 276 \\
Beijing & 16 & - & 211 & 73 \\
Shanghai & 13 & - & 193 & 66 \\
Frankfurt am Main & 10 & 9 & 58 & 62 \\
\hline
\end{tabular}

Table 1. The number of employees in the financial sector (in 000's)

Note: Cities are defined as: Hong Kong - SAR; Beijing, Shanghai - municipality; Paris - Ile-de-France; Frankfurt am Main - Stadt; Tokyo - Prefecture (Tokyo-to); London - Greater London; New York - New York-Northern Jesrsey-Long Island Metropolitan Statistical Area (MSA); Boston - Boston-Cambridge-Quincy MSA; Chicago - Chicago-Naperville-Joliet MSA. Data for Germany is for 1999 and 2008; Japan - 1996 and 2006; otherwise for 1998 and 2008. The definitions of securities industry and credit $\&$ insurance industry are not fully comparable between countries.

Sources: National Bureau of Statistics of China; Unistatis (France); Bundesagentur für Arbeit Statistik (Germany); Japanese Statistics Bureau; NOMIS, Office for National Statistics (UK); County Business Patterns, U.S. Census Bureau 